\title{
CLINICAL MASTITIS IN MACEDONIAN DAIRY HERDS
}

TRAJCEV M*, NAKOV D*, HRISTOV $\mathrm{S}^{* *}$, ANDONOV $\mathrm{S}^{*}$ and JOKSIMOVIC-TODOROVIC MIRJANA**

*University "St. Cyril and Methodius", Faculty of Agricultural Sciences and Food, Skopje, Republic of Macedonia; **University of Belgrade, Faculty of Agriculture, Serbia

(Received 5th September 2012)

The purpose of this study is the determination of the occurrence and prevalence of clinical mastitis and lactation incidence risk on three dairy farms. A one year study on a total of 1031 black-white breed cows with a total of 1267 lactations was performed. Each dairy farm implemented a different technology of rearing and was of different herd size (farm A - tie-stalls, 162 cows; farm B - loose-housing system with open shed and deep bedding, 357 dairy cows; and farm C - loosehousing system with enclosed shed, 512 cows). Clinical mastitis in cows was detected by clinical examination of the udder and determination of abnormalities in the milk. To distinguish two consecutive cases of clinical mastitis within the same lactation a time period of nine days was used.

Annual prevalence rate of clinical mastitis for the entire population of cows was $34.13 \%$ on cow level, and $30.07 \%$ on lactation level. There was a high prevalence rate of clinical mastitis in primiparous cows, $21.43 \%, 40.77 \%$ and $12.55 \%$, on farms $A, B$ and C, respectively. Lactation incident risk for cows on farm $A$ was $25.00 \%$, farm $B$ 95.58\% and farm C $21.49 \%$. The prevalence of clinical mastitis and lactation incidence risk tended to increase with increasing parity. The annual lactation risk for the entire population of cows was $45.86 \%$. All indicators for the determination of the occurrence of clinical mastitis in dairy farms, which were observed during the research, showed the greatest values on farm $B$.

Most of the cows manifested one (68.24\%) or two (18.63\%) cases of clinical mastitis during lactation. There was a long period in lactation until the appearance of the first case of clinical mastitis (112.21 \pm 92.04 days). Generally, clinical mastitis was registered during the whole period of the survey, with some fluctuations between different seasons.

The method of GLM (General Linear Model), univariate procedure, was used to analyze associations between the incidence of clinical mastitis and farm management, parity of cows and season of the year. Pearson's coefficient of correlation was performed for analysis of interdependence on variables in the model. There was statistical 
significance $(p<0,001)$ between the season and incidence of clinical mastitis.

Key word: clinical mastitis, lactation incident risk, milking cows, prevalence

\section{INTRODUCTION}

Mastitis is the most frequent and costly production disease affecting dairy cattle (Berry et al., 2003). The disease has a great influence on productivity and utilization of genetic potential of dairy cows (Hogan et al., 1989). Records for the occurrence of clinical mastitis in dairy cows are of great importance for monitoring the health status of the mammary glands and implementation of programs for control and eradication of this disease.

The incidence and prevalence of clinical mastitis reported in the literature vary considerably due to differences in the definitions of the disease or criteria used for inclusion of the cases. Therefore, the disease incidence and prevalence estimated in different studies can vary even if the real disease frequencies were similar. The authors used different time intervals during lactation for distinguishing one case from a new case of clinical mastitis (Frei et al., 1997; Kossaibati et al., 1998; Vazquez et al., 2009).

Studies in which the year incidence of clinical mastitis was measured as a number of cases per 100 cows have reported rates between 4.2 and 128.6 cases per 100 cows (Hogan et al., 1989; Shpigel et al., 1998). Other studies have measured the incidence as the number of clinical mastitis cases per 100 lactation, and rates between 19 and 92 have been reported (Sargeant et al., 1998). According to Shpigel et al. (1998) lactation incidence risk increased from the first to fifth lactation, and then decreased.

Incidences of clinical mastitis also vary considerably by country or region where the surveys have been made. According to Plym-Forshell et al. (1995), the incidence of clinical mastitis in Sweden, Norway, Denmark and Finland was 21, 30, 56 and 32 cases per 100 cow/year. According to Sviland and Waage (2002) the incidence of clinical mastitis in Norway for the period from 1992 to 1995 was 49 cases per $100 \mathrm{cow} / \mathrm{year}$, and lactation incidence risk was 32-34\%.

Literature data from countries which are the biggest milk producers, informed that per year 20 to $40 \%$ of dairy cows have expressed clinical mastitis during lactation (Bartlett et al., 2001). Despite this, presumably in the U.S. and Canada, even $50 \%$ of cows have one or more quarters infected (Hogan et al., 1989). A study from Netherlands (Barkema et al., 1998) had shown out that the incidence of clinical mastitis in dairy herds was 13 to 26 cases per $100 \mathrm{cow} / \mathrm{years}$. According the research of Workineh et al. (2002), prevalence of clinical mastitis in Ethiopia, the most populated cattle country in Africa, varied from 1.2 to $23.5 \%$.

In the Republic of Macedonia there is no available information for the occurrence of clinical mastitis in dairy herds until now. The information and records on clinical mastitis will be a good basis for successful implementation of health management and introduction of national mastitis prevention program. 


\section{MATERIALS AND METHODS}

The performed research was cross-sectional longitudinal, for the period February the $1^{\text {st }} 2009$ until January $31^{\text {st }} 2010$. The research was made on three representative dairy farms for intensive breeding, located in the Republic of Macedonia. Each of these farms differs in the system and rearing technology, size of the herd, hygiene and health management.

Management practice in farm A relies on tie-stalls. Milking of cows is performed with a transferable milking system. Pre-milking and post-milking hygiene measurements were not practiced. Management practice in farm B is based on the loose-housing system with open shed, on deep bedding. Milking of cows is performed in a milking parlour. Pre-milking and post-milking hygiene measurements were practiced permanently. Management practice in farm $C$ is production in a loose-housing system with an enclosed shed. Milking of cows is performed in a milking parlour. Pre-milking and post-milking hygiene measurements were practiced on a regular basis.

Data for each dairy cow were taken separately from the reproduction chart. During the study period, 1031 cows of black-white breed, with a total of 1267 lactations were studied. From those, in farm A the study group was consisted of 162 dairy cows with 204 lactations, in farm B 357 dairy cows with 407 lactations were followed and in farm $\mathrm{C}$ were followed 512 dairy cows with 656 lactations.

The research was divided into four seasons during the year (Trajcev, 1996). Season 1 or spring, which covers March, April and May, season 2 or summer (June, July and August), season 3 or autumn (September, October and November) and season 4 or winter (December, January and February).

Cows with clinical mastitis were detected by clinical examination of the udder (rubor, tumor, color, dolor and functio laesa) and determination of milk abnormalities (presence of watery milk, flakes, clots, blood, pus, discolored milk, etc.) and disorders of general health (IDF, 1987). The incidence of new cases of clinical mastitis was recorded daily, during the whole period of research. Within the same lactation, to distinguish two consecutive cases of clinical mastitis a period of nine days was used; respectively four days antibiotic treatment of infected quarters, another four days when antibiotics persist in the milk and the ninth day when there was not any abnormal change in the milk (Sviland and Waage, 2002).

The parameters used for the calculation of the occurrence of clinical mastitis were: prevalence rate of clinical mastitis per 100 cows/year at risk, prevalence rate of clinical mastitis per 100 lactations/year and lactation incidence risk (LIR). The prevalence of clinical mastitis was evidenced on farm level, cow level and lactation level. The annual observation period for every cow begun on February the $1^{\text {st }} 2009$ and lasted until January the $31^{\text {st }} 2010$, or from the day within the frame of the observed period when lactation started until the day when lactation finished or the cow was removed from the herd. (2007):

Prevalence of clinical mastitis was calculated according to Thrusfield 
Prevalence rate per cow $(\%)=\frac{\text { number of cows with clinical mastitis }}{\text { total number of observed dairy cows }} \times 100$
Prevalence rate per lactation $(\%)=\frac{\text { number of lactations with clinical mastitis }}{\text { total number of observed lactations }} \times 100$

Lactation incidence risk (LIR) was calculated using the density method:

$$
\operatorname{LIR}(\%)=\frac{\text { total number of clinical mastitis cases }}{\text { total number of observed lactations }} \times 100
$$

Parity of cows was calculated from the number of consecutive lactations. Age of the observed cows was from the first to the sixth lactation. Cows with more than six lactations were included in the group of cows in the sixth and further lactations.

Year season when the case of clinical mastitis was diagnosed was calculated respective to the four season during year: 109 (Spring - March $1^{\text {st }} 2009$ until May $31^{\text {st }}$ 2009), 209 (Summer - June $1^{\text {st }}$ until August $31^{\text {st }}$ 2009), 309 (Fall September $1^{\text {st }}$ until November $30^{\text {th }} 2009$ ) and 409 (Winter - December $1^{\text {st }} 2009$ until February $28^{\text {th }}$ 2010).

Statistical procedures were conducted in SPSS 6.1 for Windows, Student version. Pearson's coefficient of correlation was used for the calculation of interdependence between variables. Data analysis was carried out with GLM (General Linear Model). The dependent variable in these analyses was the binary value of clinical mastitis i.e. the difference between cows with clinical mastitis during lactation and healthy cows. Statistical significance was evaluated on level $\mathrm{p}<0.05, \mathrm{p}<0.01$ and $\mathrm{p}<0.001$.

Analysis of variance in the model, used for the determination of the influence of independent variables on the incidence of clinical mastitis between dairy cows, was made according to the equation:

$$
Y i j k=\mu+F_{i}+L_{j}+Y S_{-} C M_{k}+e_{i j k}
$$

$\mathrm{Y}_{\mathrm{ijk}}=$ calculated value of clinical mastitis incidence;

$\mu=$ average;

$F_{i}=$ farm management $(i=1,2,3)$;

$L_{j}=$ consecutive lactation or cow parity $(j=1,2,3,4,5,6)$;

YS_ $\mathrm{CM}_{\mathrm{k}}=$ year season when the case of clinical mastitis during lactation was diagnosed $(\mathrm{k}=109,209,309,409)$;

$\mathrm{e}_{\mathrm{ijk}}=$ error of the model.

\section{RESULTS}

The annual prevalence of clinical mastitis, calculated as the rate between diseased cows and all observed cows, is shown in Table 1. 
Table 1. Annual prevalence rate of clinical mastitis per 100 cows in lactation

\begin{tabular}{|c|c|c|c|c|}
\hline Farms & $\begin{array}{c}\text { Cows with } \\
\text { clinical mastitis }\end{array}$ & Healthy cows & $\begin{array}{c}\text { Total number } \\
\text { of cows }\end{array}$ & $\begin{array}{c}\text { Prevalence rate } \\
\text { per 100 cows, \% }\end{array}$ \\
\hline \hline A & 40 & 122 & 162 & 24.69 \\
\hline B & 181 & 176 & 357 & 50.70 \\
\hline C & 131 & 381 & 512 & 25.59 \\
\hline \hline Total & 352 & 679 & 1031 & 34.14 \\
\hline
\end{tabular}

According the results, the largest annual prevalence was calculated in the dairy herd on farm B (50.70\%) compared to farm A (24.69\%) and farm C (25.59\%). The total prevalence rate of clinical mastitis for the entire population of dairy cows, calculated per 100 cows/year at risk, was 34.14\%.

The annual prevalence of clinical mastitis calculated per 100 lactations is shown in Table 2.

Table 2. Annual prevalence rate of clinical mastitis per 100 lactations

\begin{tabular}{|c|c|c|c|c|}
\hline Farms & $\begin{array}{c}\text { Lactations with } \\
\text { case of clinical } \\
\text { mastitis }\end{array}$ & $\begin{array}{c}\text { Lactations without } \\
\text { case of clinical } \\
\text { mastitis }\end{array}$ & $\begin{array}{c}\text { Total number } \\
\text { of lactations }\end{array}$ & $\begin{array}{c}\text { Prevalence rate } \\
\text { per } 100 \\
\text { lactations, \% }\end{array}$ \\
\hline \hline A & 41 & 163 & 204 & 20.10 \\
\hline B & 209 & 198 & 407 & 51.35 \\
\hline C & 131 & 525 & 656 & 19.97 \\
\hline \hline Total & 381 & 886 & 1267 & 30.07 \\
\hline
\end{tabular}

According to the results, annual prevalence per 100 lactation on farm $B$ was $51.35 \%$, and was more than twice higher than the prevalence on farm A $(20.10 \%)$ and farm C (19.97\%). The total prevalence of clinical mastitis for the entire observed population of dairy cows, calculated per 100 lactations, was $30.07 \%$.

The annual prevalence of clinical mastitis, calculated separately for cows in different lactations, is shown in Table 3.

Table 3. Annual prevalence rate of clinical mastitis calculate for cows in different lactations

\begin{tabular}{|c|c|c|c|c|c|c|c|}
\hline Parameter & \multicolumn{6}{|c|}{ Lactation } & \multirow{2}{*}{ Total } \\
\hline Farms & 1 & 2 & 3 & 4 & 5 & $6 \geq^{*}$ & \\
\hline \hline A & $21.43 \%$ & $13.95 \%$ & $8.51 \%$ & $26.47 \%$ & $31.82 \%$ & $37.50 \%$ & $20.10 \%$ \\
\hline B & $40.77 \%$ & $52.58 \%$ & $59.26 \%$ & $59.18 \%$ & $46.67 \%$ & $62.50 \%$ & $51.35 \%$ \\
\hline C & $12.55 \%$ & $21.77 \%$ & $19.23 \%$ & $30.93 \%$ & $22.73 \%$ & $47.06 \%$ & $19.97 \%$ \\
\hline \hline Total & $22.20 \%$ & $31.01 \%$ & $33.98 \%$ & $37.78 \%$ & $29.63 \%$ & $46.34 \%$ & $30.07 \%$ \\
\hline
\end{tabular}

${ }^{*}$ cows in sixth or further lactation or parity 
According to the results (Table 3 ) the prevalence of clinical mastitis in the entire population of dairy cows increased with parity, or consecutive lactation, beginning from the first lactation $(22.20 \%)$ up to the sixth and further lactation (46.34\%). This increase in clinical mastitis prevalence with increasing cows' parity did not show statistical significance. Independent from lactation, the prevalence of clinical mastitis was high on all three farms.

Prevalence rate of clinical mastitis in primiparous cows has been very high on all three farms, particularly on farm B, where the prevalence was $40.77 \%$. The prevalence of clinical mastitis in primiparous cows had the lowest rate on farm C $(12.55 \%)$ in relation to primiparous cows on other farms.

In Table 4 is shown the number of cases of clinical mastitis during lactation and occurrence of recurrent cases during the same lactation.

Table 4. Repeatability of clinical mastitis cases per lactation

\begin{tabular}{|c|c|c|c|c|c|c|}
\hline \multicolumn{7}{|c|}{ Cows in lactation that experienced } \\
\hline Farms & $\begin{array}{c}1 \text { case of } \\
\mathrm{CM}^{*}\end{array}$ & $\begin{array}{c}2 \text { cases of } \\
\mathrm{CM}\end{array}$ & $\begin{array}{c}3 \text { cases of } \\
\mathrm{CM}\end{array}$ & $\begin{array}{c}4 \text { cases of } \\
\mathrm{CM}\end{array}$ & $\begin{array}{c}5 \text { cases of } \\
\mathrm{CM}\end{array}$ & $\begin{array}{c}6 \text { cases of } \\
\mathrm{CM}\end{array}$ \\
\hline \hline $\mathrm{A}$ & $82.92 \%$ & $9.75 \%$ & $7.31 \%$ & & & \\
\hline $\mathrm{B}$ & $50.23 \%$ & $27.27 \%$ & $12.44 \%$ & $7.17 \%$ & $1.91 \%$ & $0.95 \%$ \\
\hline $\mathrm{C}$ & $92.36 \%$ & $7.63 \%$ & & & & \\
\hline \hline Total & $68.24 \%$ & $18.63 \%$ & $7.61 \%$ & $3.93 \%$ & $1.04 \%$ & $0.52 \%$ \\
\hline
\end{tabular}

${ }^{*} \mathrm{CM}$ - clinical mastitis

From analysis of results shown in Table 4 it may be noticed that most cows suffered from clinical mastitis once during the same lactation, and cows suffering from recurrent consecutive mastitis (twice, three, four or more times) were rare. The most prevalent occurrence of recurrent clinical mastitis during lactation was registered in the dairy herd situated on farm $B$.

From a total of 381 cows in lactation, who suffered from clinical mastitis, 260 cows $(68.24 \%)$ suffered from only one case of clinical mastitis, 71 cows $(18.63 \%)$ manifested two cases, 29 cows (7.61\%), 15 cows (3.93\%) suffered from four cases of clinical mastitis, 4 cows (1.04\%) manifested five cases and 2 cows $(0.52 \%)$ suffered from six cases of clinical mastitis during the same lactation.

Table 5. Lactation incidence risk for clinical mastitis

\begin{tabular}{|c|c|c|c|c|c|c|c|}
\hline Parameter & \multicolumn{7}{|c|}{ Lactation } \\
\hline Farms & 1 & 2 & 3 & 4 & 5 & $6 \geq^{*}$ & Total \\
\hline \hline A & $23.81 \%$ & $20.93 \%$ & $17.02 \%$ & $32.35 \%$ & $31.82 \%$ & $37.50 \%$ & $25.00 \%$ \\
\hline B & $83.08 \%$ & $100.00 \%$ & $105.56 \%$ & $108.16 \%$ & $66.67 \%$ & $87.50 \%$ & $95.58 \%$ \\
\hline C & $13.36 \%$ & $26.53 \%$ & $19.23 \%$ & $31.96 \%$ & $22.73 \%$ & $47.06 \%$ & $21.49 \%$ \\
\hline \hline Total & $36.04 \%$ & $50.52 \%$ & $54.83 \%$ & $52.78 \%$ & $33.33 \%$ & $51.22 \%$ & $45.86 \%$ \\
\hline
\end{tabular}

* cows in sixth or further lactation or parity 
LIR (Lactation Incidence Risk), calculated as the rate of total number of clinical mastitis cases per total number of observed lactations, for a one year period, is shown in Table 5.

According to the shown results, dairy cows on farm $B$ had the highest risk of suffering from clinical mastitis $(95.58 \%$ of lactating dairy cows). This practically means that on farm $B$ approximately every cow in lactation had the risk to manifest at least one case of clinical mastitis. If we compare the lactation incidence risk in primiparous cows, we can notice that the primiparous cows on farm $\mathrm{C}$ had the lowest lactation incidence risk (13.36\%) to become ill from clinical mastitis compare with the lactation incidence risk in primiparous cows on farm A $(23.81 \%)$ and on farm B (83.08\%). The lactation incidence risk in the entire population of dairy cows was $45.86 \%$. LIR in the entire population, calculated for the whole observed period, increased with increasing parity, or consecutive lactation, beginning from cows in the first lactation (36.04\%) up to cows in the third lactation $(54.83 \%)$, and then decreasing.

Figure 1 showes the average number of days in lactation until the first case of clinical mastitis was diagnosed.

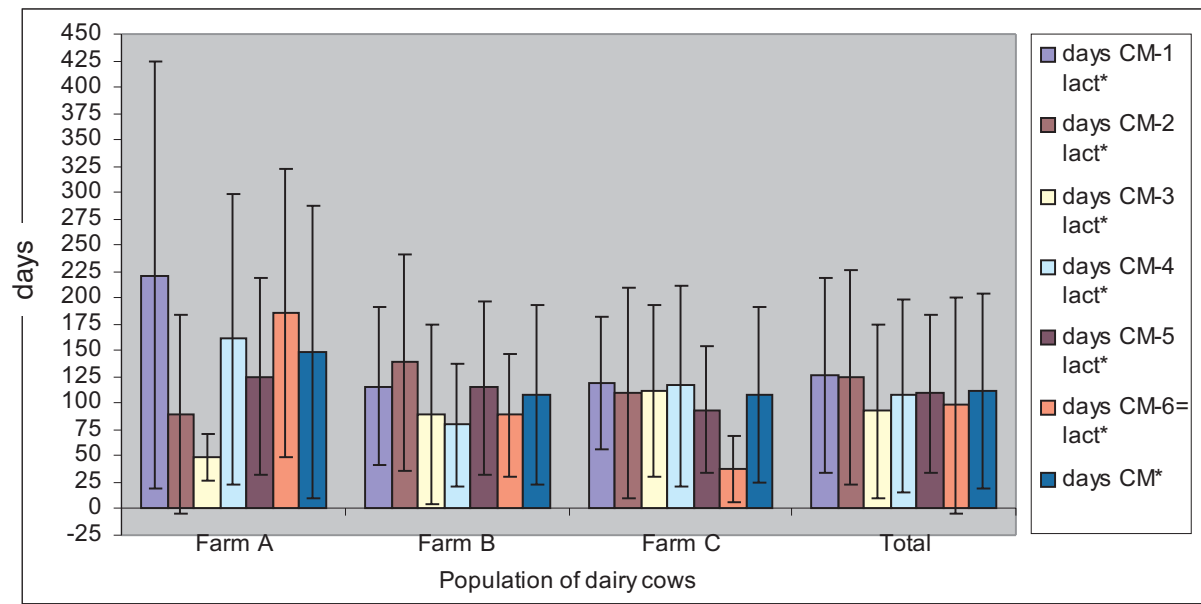

*Average number of days in lactation and standard deviation for cows in different parity until the first case of clinical mastitis

Figure 1. Average number of days and standard deviation from beginning of lactation until diagnosed first case of clinical mastitis

From results in Figure 1 can be seen that there is a big difference in the average number of days during lactation until the first case of clinical mastitis was diagnosed. On farm A, regardless of parity or number of consecutive lactations, the first case of clinical mastitis occurred after on average $148.70 \pm 138.33$ days in lactation. Regardless of parity, or number of consecutive lactations, the first case of clinical mastitis in the dairy herd on farm B occurred after 107.86 \pm 85.15 days in lactation. On farm $\mathrm{C}$, regardless of parity, or number of consecutive lactation, 
the first case of clinical mastitis occurred after $108.09 \pm 83.18$ days of lactation. Average number of days from the beginning of lactation until the first case of clinical mastitis, for the entire population of dairy cows, regardless from parity or number of consecutive lactations, was $112.21 \pm 92.04$ days.

Figure 2 showed comparatively all parameters that represent the risk for the occurrence of clinical mastitis in dairy cows.

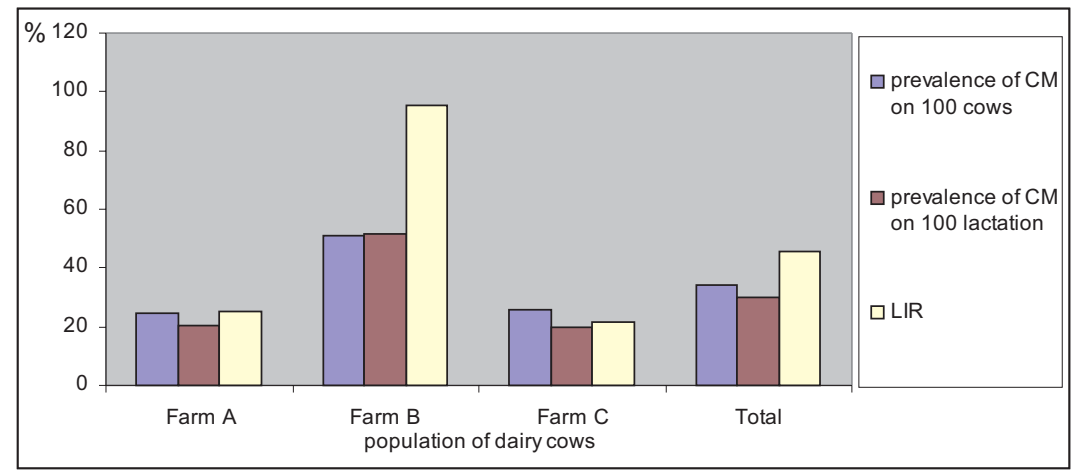

Figure 2. Risk parameters for occurrence of clinical mastitis in dairy cows

All risk parameters, that were investigated during the research, showed the highest prevalence of clinical mastitis and the highest risk for the disease in the dairy herd on farm $B$ in relation to farm $A$ and farm $C$.

Occurrence of clinical mastitis in all three farms, that were included in the research, was recorded during the year, showing seasonal variations (Figure 3).

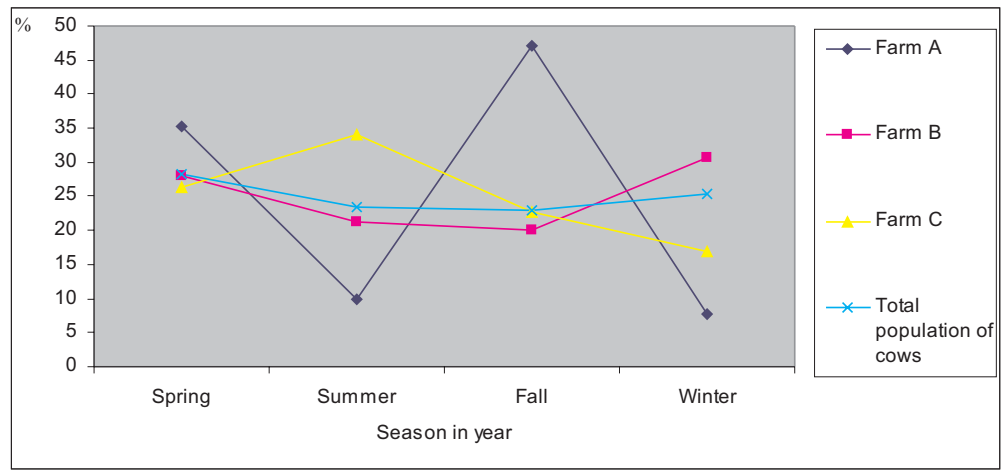

Figure 3. Distribution of clinical mastitis per year seasons

On farm A most of the cases of clinical mastitis were recorded in spring (35.29\%) and fall (47.05\%), while the number of clinical mastitis cases recorded in summer and winter were the least, $9.80 \%$ and $7.84 \%$, respectively. However, on farm B most of the clinical cases were recorded in winter (30.59\%). A high rate of 
cows that suffered from clinical mastitis was recorded in spring (28.02\%). The rate of cows that suffered from clinical mastitis in the summer and fall was approximately similar $(21.33 \%$ and $20.05 \%)$. On farm C most of the cases of clinical mastitis were recorded in summer (34.04\%), and the lowest number of cases of clinical mastitis was recorded in winter (17.02\%). In spring and fall were recorded $26.24 \%$ and $22.69 \%$ cases of clinical mastitis, respectively.

Estimation of interdependence between variables in the statistical model was performed with Pearson's coefficient of correlation (Table 6).

Table 6. Pearson's coefficient of correlation

\begin{tabular}{|c|c|c|c|}
\hline Pearson's & $\mathrm{L}$ & YS_CM & CM \\
\hline \hline $\mathrm{F}$ & $-0.103^{\star *}$ & $-0.165^{\star \star}$ & $0.179^{\star *}$ \\
\hline $\mathrm{L}$ & 1 & $0.098^{\star *}$ & $-0.087^{\star *}$ \\
\hline YS_CM & & 1 & $-0.882^{\star *}$ \\
\hline
\end{tabular}

** significant at the $p<0,01$ level

Statistical analysis of the factors considered in the model used for determination of influence on independent variables on the incidence of clinical mastitis between dairy cows is shown in Table 7 .

Table 7. Influence of independent variables on incidence of clinical mastitis

\begin{tabular}{|c|c|c|c|}
\hline \multicolumn{5}{|c|}{ Dependent variable: incidence of clinical mastitis } \\
\hline Source of variations & df & Mean square & F-value \\
\hline \hline Model & 12 & 538.5836663 & $1102577.04^{\star \star \star}$ \\
\hline F & 2 & 0.000686378 & $1.405130301^{\mathrm{NS}}$ \\
\hline L & 5 & 0.000335313 & $0.685892485^{\mathrm{NS}}$ \\
\hline YS_CM & 4 & 82.93927205 & $169791.5158^{\star \star *}$ \\
\hline e & 2039 & 0.000488477 & \\
\hline \hline Total & 2051 & & \\
\hline \hline
\end{tabular}

*** significant at the $p<0.001$ level; ${ }^{N S}$ no significant

There was statistical significance $(p<0.001)$ for the influence of the seasons. Value for $R^{2}=1.000$ in the model was high, which means that variance for the incidence of clinical mastitis can be explained by the source of variations.

\section{DISCUSSION}

The high prevalence and risk for clinical mastitis makes considerable economic losses on dairy farms. The fact that mastitis is the classic example for multifunctional disease led to the presumption that differences in prevalence 
between farms was the result of differences in farm management and environment, differences in breeding systems, hygiene and health management, milk production and genetic variations between cows and resistance to mastitis. However, in our statistical model, farm management did not show a statistically significant influence on the incidence of clinical mastitis.

According to literature data, there are various opinions about the influence of farm management, herd size and breeding system on the incidence of clinical mastitis (Waage et al., 1998; Schnier et al., 2002; Faldelmoula et al., 2007). The results of our research indicate better health status of mammary glands of cows housed in tie-stalls compared with cows bred in a housing system with open sheds.

According to our results, annual prevalence of clinical mastitis was similar to that reported by Firat (1993), when the prevalence was $35.8 \%$, and approximately similar to results reported by Barkema et al. (1998) and Workineh et al. (2002), when the prevalence was $24-26 \%$. On the other hand, the prevalence of clinical mastitis in our research was higher than the prevalence reported by Rajala and Grohn (1998), where the it ranged from 5.3 to $18.8 \%$, but was also lower than the results reported by Faull et al. (1983). Similar results for the prevalence of clinical mastitis like on farm A and farm C were reported by Sargeant et al. (1998), where the prevalence was $19.8 \%$. Annual prevalence of clinical mastitis on farm B was $50.70 \%$ per 100 cows/year and $51.35 \%$, per 100 lactations/year. These results were very similar to those reported by Gonzalez et al. (1989). According these results, the prevalence of clinical mastitis ranged from 44.6 to $53 \%$.

Literature data are generally consistent about the reports that with increasing the parity of cow or the number of consecutive lactation, also increases the risk for clinical mastitis (Barkema et al., 1998; Sargeant et al., 1998), whereupon the peak is reached in the second or the third lactation (Verhoef et al., 1981), and after the fourth lactation there is not a definite trend (Batra et al., 1977). According to Rajala et al. (1999), the prevalence of clinical mastitis for cows in the first, second and third lactation was $12.1 \%, 14.3 \%$ and $14.9 \%$, respectively, while Carlen et al. (2006) reported a little higher prevalence, when it was 15, 18 and $22 \%$, for cows in first, second and third lactation, respectively. Contrary to these reports, Lescouret et al. (1995) in their research did not find significant influence of lactation on the occurrence of clinical mastitis.

Prevalence of clinical mastitis in primiparous cows was very high on all three dairy farms. This concerns, especially if we have foresight that primiparous cows are the true potential of every dairy farm, so the health status of their mammary gland affects future milk production and quality. The prevalence of clinical mastitis was higher in primiparous cows in farm B. This is likely due to high milk production, occurring udder oedema after calving and hygiene management of the maternity area after calving.

According to many authors, the incidence of clinical mastitis in primiparous and multiparous cows is more frequent in dairy herds with high milk production (Myllys and Rautalla, 1995; Erskine, 2001). Another research by Waage et al. (2001) showed out that primiparous cows have a higher probability to manifested udder oedema after calving, additionally increasing the incidence risk for clinical 
mastitis. Contrary to these reports, Slettbakk et al., (1990) did not find a connection between udder oedema after calving and disorders of udder health status.

According to the research of Sviland and Waage (2002) $26 \%$ of dairy cows manifested two or more cases of clinical mastitis during the same lactation. There have been similar reports from Canada, where $27 \%$ of dairy cows suffered from recurrent consecutive cases (two, three, four or more) of clinical mastitis during the same lactation (Bigras-Poulin et al., 1990). Hogan et al., (1989) reported that recurrent clinical mastitis during the same lactation occurred in dairy cows in 35\% to $60 \%$ cases. This result can lead to an expectation that dairy cows with recurrent consecutive cases of clinical mastitis during the same lactation were more prevalent than cows suffering only once, and proportionally in the next lactation would have double the risk to suffer from mastitis (Wolfova et al., 2006). Therefore, when assessing the risk of clinical mastitis in dairy cows, recurrent cases should be taken into account. It is likely that only $10-11 \%$ cows not suffering from clinical mastitis in the previous lactation will develop clinical mastitis in the next lactation (Firat, 1993).

Inappropriate implementation of hygiene measurements and antimicrobial therapy of infected quarters was a reason for clinical mastitis to become subclinical mastitis, with a probability for the occurrence of new cases of clinical mastitis (Trajcev and Nakov, 2009).

Lactation incidence risk gives good a picture for the problems that clinical mastitis could make in dairy cattle farms. In our research, the obtained rates for LIR fit the wide range of values according the literature data, ranged from 19 to 92 cases of clinical mastitis per 100 lactations/year (Sargeant et al., 1998; Kadarmideen and Pryce, 2001). According to the research of Sviland and Waage (2002), lactation incidence risk in Norwey, for cows calving in the years 1992, 1993 and 1994 it was proportionally $32 \%$; $33 \%$ and 34\%, respectively. Heringstad et al. (2003) reported values of LIR from 15\%, 19\% and $24 \%$ for the first, second and third parity, respectively. Similar records were given by Shpigel et al. (1998), when LIR was 20.8 cases per 100 lactations/year, with variations ranging from 4.2 to 126.8 cases per 100 lactations/year. These authors confirmed that values for LIR increase in cows from the first up to fifth lactation, and after that decrease up to eighth lactation. The values that these authors got for LIR were 14.3, 19.6, 26.7, $27.4,29.2,22.3,26.2$ and 17.9 cases per 100 cows/year respectively for cows in $1^{\text {st }}, 2^{\text {nd }}, 3^{\text {rd }}, 4^{\text {th }}, 5^{\text {th }}, 6^{\text {th }}, 7^{\text {th }}$ and $8^{\text {th }}$ lactation, respectively.

Incidence risk for clinical mastitis was the highest in the first several days after calving, or $30 \%$ of all cases occurred in the first 14 days of lactation (Barkema et al., 1998). Our results were rather similar to the results given by Shpigel et al. (1998). According to the authors, $51.4 \%$ from all cases of clinical mastitis occurred within early and middle lactation, or approximately 117.5 days in lactation. These authors explained the increased risk for clinical mastitis in early lactation by a positive correlation between intensive milk production and mastitis.

Seasonal variations for occurence of clinical mastitis during the year were small, and ranged from $23.06 \%$ to $28.22 \%$. However, seasonal variations during the year had a statistically significant influence on the incidence of clinical mastitis. 
For the entire population of dairy cows, we can separate the spring and fall seasons when the prevalence of clinical mastitis reaches upper limits. Climate characteristics in Macedonia make these seasons to be period of the year with the most rainfall, which corresponds to hygiene facilities and microclimatic conditions inside the farms. These microclimatic conditions are risk factors for the occurrence of clinical mastitis in dairy cows. According to literature data, rainfalls and moisture have influenced the incidence of clinical mastitis (Myllys and Rautala, 1995; Rahman et al., 2009). The biggest prevalence of clinical mastitis during the winter seasons on farm B probably was the result of longer time of prrostration of cows on the bedding in the stalls because of lower inside air temperature. These made the temperature of the bedding material to seem warmer, so the environmental conditions for growth of pathogens, which are potential causes of clinical mastitis, become suitable. Despite these findings, other authors did not find a significant influence of seasonal variations on the incidence of clinical mastitis (Jones and Wars, 1989).

ACKNOWLEDGEMENTS:

This research paper was partially financed by the project TR 31086 .

Address for correspondence:

Trajcev Metodija, DVM, PhD

Institute for animal biotechnology

Faculty of Agricultural Sciences and Food

University „St. Cyril and Methodius“, Skopje

Blvd. Aleksandar Makedonski nn

1000 Skopje, Republic of Macedonia

E-mail: nakovd@zf.ukim.edu.mk

\section{REFERENCES}

1. Barkema HW, Schukken YN, Lam TJGM, Beiboer ML, Benedictus G, Brand A, 1998, Management practices associated with low, medium, and high somatic cell counts in bulk milk, J Dairy Sci, 81, 1917-27.

2. Bartlett PC, Agger JF, Houe H, Lawson LG, 2001, Incidence of clinical mastitis in Danish dairy cattle and screening for non-reporting in a passively collected national surveillance system, Prev Vet Med, 48, 73-83.

3. Batra TR, Nonnecke BJ, Newbould FHS, Hacker RR, 1977, Incidence of clinical mastitis in a herd of Holstein cattle, J Dairy Sci, 60, 1169-72.

4. Berry DP, Buckley F, Dillon P, Evans RD, Rath M, Veerkamp RF, 2003, Genetic relationships among body condition score, body weight, milk yield and fertility in dairy cows, J Dairy Sci, 86, 2193204.

5. Bigras-Poulin M, Meek AH, Martin SW, 1990, Interrelationships of health problems and age on milk production in selected Ontario Holstein cows, Prev Vet Med, 8, 3-13.

6. Carlen E, Emanuelson U, Strandberg E, 2006, Genetic evaluation of mastitis in dairy cattle using linear models, threshold models, and survival analysis: A simulation study, J Dairy Sci, 89, 4049-57.

7. Erskine RJ, 2001, Mastitis Control in Dairy Herds. In Radostits Otto M.: Herd Healt Fooh Animal Production Medicine, Third Edition. W.B. Saunders Company, Philadelphia, London, New York, St.Louis, Sydney, Toronto, 397-433.

8. Fadlelmoula AA, Anacker G, Fahr RD, Swalve HH, 2007, The Management Practices Associated with Prevalence and Risk Factors of Mastitis in Large Scale Dairy Farms in Thuringia, Germany (II Management and Hygienic), Aust J Basic Appl Sci, 1, 4, 751-5. 
9. Faull WB, Walton JR, Bramley AJ, Hughes JW, 1983, Mastitis in a large, zero-grazed dairy herd, Vet Rec, 113, 415-20.

10. Firat MZ, 1993, Susceptibility of clinical mastitis in successive lactations, Livestock Prod Sci, 34, 12, 175-80.

11. Frei C, Frei PP, Stark KDC, Pfeiffer DU, Kihm U, 1997, The production system and disease incidence in a national random longitudinal study of Swiss dairy herds, Prev Vet Med, 32, 1-21.

12. Heringstad B, Rekaya R, Gianola D, Klemetsdal G, Weigel KA, 2003, Genetic change for clinical mastitis in Norwegian cattle: A threshold model analysis, J Dairy Sci, 86, 369-75.

13. Hogan JS, Smith KL, Hoblet KH, Schoenberger PS, Todhunter DA, Hueston WD, Pritchard DE, Bowman GL, Heider LE, Brockett BL, Conrad HR, 1989, Field survey of clinical mastitis in low somatic cell count herds, J Dairy Sci, 72, 1547-56.

14. International Dairy Federation, 1987, Bovine Mastitis, Definitions and guidelines for diagnosis, Bull Int Dairy Federation, 211, 3-8.

15. Jones GF, Wars GE, 1989, Cause, occurrence and clinical signs of mastitis and anorexia in cows in a Wisconsin study, J Am Vet Med Assoc, 195, 1108-13.

16. Kadarmideen HN, Pryce JE, 2001, Genetic and economic relationships between somatic cell count and clinical mastitis and their use in the selection for mastitis resistance in dairy cattle, Anim Sci, 73, 19-28.

17. Kossaibati MA, Hovi M, Esslemont RJ, 1998, Incidence of clinical mastitis in dairy herds in England, Vet Rec, 143, 649-53.

18. Myllis V, Rautala H, 1995, Characterization of Clinical Mastitis in Primiparous Heifers, J Dairy Sci, 78, 538-45.

19. Plym-Forshell K, Osteras O, Aagaard K, Kulkas L, 1995, Disease recording and cell count data in 1993, in Sweden, Norway, Denmark and Finland, Proceedings of the 3rd International Mastitis Seminar, Tel Aviv, Israel, Session 4, 50-4.

20. Rahman MA, Bhuiyan MMU, Kamal MM, Shamsuddin M, 2009, Prevalence and risk factors of mastitis in dairy cows, Bangladesh Vet, 26, 2, 54-60.

21. Rajala PJ, Grohn YT, 1998, Disease occurrence and risk factor analysis in Finnish Ayrshire cows, Acta Vet Scand, 39, 1, 1-13.

22. Rajala-Schultz PJ, Grohan JT, McCulloch CE, Guard CL, 1999, Effects of Clinical Mastitis on Milk Yield in Dairy Cows. J Dairy Sci, 82, 1213-20.

23. Sargeant JM, Scott M, Leslie M, Ireland KE, Bashiri MJA, 1998, Clinical mastitis in dairy cattle in Ontario: frequency of occurrence and bacteriological isolates, Can Vet J, 39, 33-8.

24. Schnier C, Hielm B, Saloniemi HS, 2002. Comparison of the disease incidences od dairy cows kept in cold and warm loose-housing system, Prev Vet Med, 53, 247-61.

25. Shpigel NY, Winkler M, Ziv G, Saran A, 1998, Clinical, bacteriological and epidemiological aspects of clinical mastitis in Israeli dairy herds, Prev Vet Med, 35, 1-9.

26. Slettbakk T, Jorstad A, Farver TB, Hird DW, 1990, Impact of milking characteristics and teat morphology on somatic cell counts in first lactation Norwegian cattle, Prev Vet Med, 24, 235-44.

27. Sviland S, Waage S, 2002, Clinical bovine mastitis in Norway, Prev Vet Med, 54, 65-78.

28. Thrusfeild M, 2007, Veterinary Epidemiology, 3rd edition, Blackwell Science Ltd, 22-33.

29. Trajcev M, 1996, Research of globulins in the colostrum and immunoglobulins in the blood serum of calves depending on the hygiene of cows, Master thesis, Faculty of Agriculture, University "Ss. Cyril and Methodius" - Skopje.

30. Trajcev M, Nakov D, 2009, Mastitis control program in dairy herds. Yearbook of the Faculty of Agricultural Science and Food, 54, 123-40.

31. Vazquez Al, Gianola D, Bates D, Weigel KA, Heringstad B, 2009, Assessment of Poisson, logit, and linear models for genetic analysis of clinical mastitis in Norwegian Red cows, J Dairy Sci, 92, 739-48.

32. Verhoeff J, Van de Geer D, Hagens FM, 1981, Effects of a mastitis control programme on the incidence of clinical mastitis, Vet Quart, 3, 158-64.

33. Waage $S$, Sviland S, Odegaard $S A, 1998$, Identification of risk factors for clinical mastitis in dairy heifers, J Dairy Sci, 81, 1275-84. 
34. Waage S, Odegaard A, Lund A, Brattgjerd S, Rothe T, 2001, Case-Control Study of Risk Factors for Clinical Mastitis in Postpartum Dairy Heifers, J Dairy Sci, 84, 392-9.

35. Wolfova M, Stipkova M, Wolf J, 2006, Incidence and Economics of Clinical Mastitis in Five Holstein Herds in the Czech Republic, Prev Vet Med, 77, 1-2, 48-64.

36. Workineh S, Bayleyegne M, Mekonnen H, Potgieter LND, 2002, Prevalence and aetiology of mastitis in cows from two major Ethiopian dairies, Trop Anim Health Product, 34, 19-25.

\title{
KLINIČKI MASTITIS NA FARMAMA MLEČNIH KRAVA U MAKEDONIJI
}

\author{
TRAJČEV M, NAKOV D, HRISTOV S, ANDONOV S i JOKSIMOVIĆ-TODOROVIĆ MIRJANA
}

\section{SADRŽAJ}

Cilj ovog rada je bio utvrđivanje pojave i prevalencije kliničkog mastitisa i laktacionog rizika na tri farme mlečnih krava. Sprovedena su jednogodišnja istraživanja na ukupno 1031 kravi crno bele rase i u 1267 laktacija. Farme su se međusobno razlikovale po tehnologiji gajenja i veličini stada (farma $A$ - vezani sistem gajenja, 162 krave; farma B - slobodni sistem gajenja na dubokoj prostirci u otvorenoj staji, 357 krava i farma C - slobodni sistem gajenja u zatvorenoj staji, 512 krava). Utvrđivanje kliničkog mastitisa vršeno je kliničkim ispitivanjem vimena i utvrđivanjem promena u mleku. Da bi se napravila razlika između dva uzastopna slučaja kliničkog mastitisa u toku iste laktacije korišćen je period od 9 dana.

Godišnja učestalost kliničkih mastitisa za celokupnu populaciju krava iznosila je 34,13\% u odnosu na ukupan broj krava i 30,07\% u odnosu na ukupan broj laktacija. $U$ toku istraživanja utvrđena je visoka prevalencija kliničkog mastitisa kod primiparnih krava i to $21,43 \%, 40,77 \%$ i $12,55 \%$ na farmama A, B i C, redom. Opseg laktacionog rizika za krave na farmi A iznosio je 25,00\%, farmi B 95,58\% i na farmi C 21,49\%. Prevalencije kliničkog mastitisa i laktacionog rizika pokazuju tendenciju rasta sa povećanjem pariteta krava. Godišnji laktacioni rizik za celokupnu populaciju krava iznosio je 45,86\%. Svi indikatori pojave kliničkog mastitisa u istraživanju pokazali su najveće vrednosti na farmi B.

Sa povećanjem pariteta ili uzastopne laktacije utvrđeno je povećanje prevalence i laktacionog rizika kliničkog mastitisa. Kod većine krava utvrđen je jedan $(68,24 \%)$ ili dva $(18,63 \%)$ slučaja kliničkog mastitisa tokom laktacije. Postojao je dug period laktacije do pojave prvog slučaja kliničkog mastitisa $(112,21 \% \pm 92,04$ dana). Uopšteno posmatrano klinički mastitis je utvrđen tokom čitavog perioda istraživanja sa izvesnim varijacijama među sezonama.

Za analizu zavisnosti između pojave kliničkog mastitisa i farme, pariteta krava i sezone, primenjen je jednovarijantni postupak GLM. Za analizu međuzavisnosti promenljivih u modelu korišćen je Pirsonov koeficijent korelacije. Utvrđena je statistički značajna razlika $(p<0,001)$ između sezone i pojave kliničkog mastitisa. 